\title{
Effects of Extruded and Extruded-Pelleted Corn Products Partially Substituted for Unprocessed Corn of the Starter Diet on Growth Performance and Incidence of Diarrhea in Weanling Pigs
}

\author{
Byung-Chul Park ${ }^{1 \dagger}$, Jeong-Cheol $\mathrm{Han}^{2 \dagger}$, Young-Hyun Ko ${ }^{2}$, Duck-Min $\mathrm{Ha}^{2}$, Doo-Hwan Kim², Insurk Jang ${ }^{2}$ and C. Young Lee ${ }^{2 *}$ \\ ${ }^{1}$ Sunjin Co., Ltd, 517-3 Doonchon-dong, Kangdong-gu, Seoul 134-060, Korea, ${ }^{2}$ Regional Animal Industry Center, \\ Gyeongnam National University of Science and Technology, Jinju 660-758, Korea
}

\begin{abstract}
The aim of the present study was to investigate the effects of partial substitution of an extruded or extruded-pelleted corn product for unprocessed corn of the starter diet on growth performance and incidence of diarrhea in weanling pigs. Seventy-two 21-day-old weanling pigs were allotted to 24 pens and provided ad libitum with one of the four experimental diets for 3 wk in two serial feeding trials during summer beginning from late June. The treatments were a milk product-soy-corn-based control diet containing $25 \%$ unprocessed corn and the other three diets only substituted with $12.5 \%$ extruded corn Suprex ${ }^{\circledR}$, Optigrain ${ }^{\circledR}$, an extruded mixture of wheat, rye and durum, or extruded-pelleted corn for an equal percentage of unprocessed corn of the control diet. All diets were supplemented with $100 \mathrm{ppm}$ sulfathiazone, $50 \mathrm{ppm}$ penicillin, and $100 \mathrm{ppm}$ chlortetracycline for preventive medication. The initial and final weights as well as gain: feed were less in the second trial than in the first one $(\mathrm{P}<0.05)$. However, effects of the dietary treatments were not detected in any of the performance variables including final weight, ADG, ADFI, and gain: feed, nor were there any interactions between the trial and dietary treatment. In addition, almost all pigs exhibited normal firm feces in both trials and therefore there was no main effect in the fecal consistency score. Results suggest that partial substitution of the thermally processed corn for unprocessed corn of the milk product-corn-soy-based and medicated starter diet has no effect on growth performance or incidence of diarrhea in weanling pigs.
\end{abstract}

(Key words : Pig, Starter diet, Corn, Feed extrusion, Diarrhea)

\section{INTRODUCTION}

Energy of complete diets for commercial pigs and other animals is provided mostly in the form of starch contained in grains, of which corn is most widely used in Korea as well as in the world. The activities of amylase and proteases, which digest starch and protein, respectively, are low in the pancreas and intestine in early nursery pigs weaned at 2 to 4 wk of age although the intestinal enzymatic activities increase with increasing consumption of the solid nursery diet (Shields et al., 1980). It is therefore important nutritionally to increase the in vivo utilization rate of the nutrients contained in the grain, especially corn, of the nursery pig diet.

Efficiency of feed ingredientsas well as the whole diet can be improved by virtue of various 'thermal' processing technologies which include pelleting, dry cooking, steaming, extrusion, expansion or 'a mild extrusion' (Peisker, 1994), and their combinations (Hancock and Behnke, 2001; Han et al., 2011). The thermal processing shears and gelatinizes starch to increase the energy digestibility (Noland et al., 1976; Herkelman et al., 1990; Li et al., 2010), denatures and shears protein usually resulting in an increase of $\mathrm{N}$ digestibility (Sauer et al., 1990; Lundblad et al., 2012), and reduces the moisture content of the processed ingredient or diet (Hancock and Behnke, 2001). Moreover, thermal processing of the grain or whole diet usually increases the feed conversion efficiency, which can result in an increase in weight gain (Wondra et al., 1995a,b) or no effect on growth performance (Noland et al., 1976; Ginste and De Schrijver, 1998; Lundblad et al., 2012) of nursery as well as growingfinishing pigs.

Sauer et al. (1990) have reported that extruding a cereal-based nursery diet was more effective than pelleting in

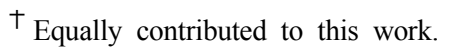

* Corresponding author: C. Young Lee, Regional Animal Industry Center, Gyeongnam National University of Science and Technology, Jinju 660-758, Korea. Tel: +82-55-751-3285, Fax: +82-55-753-4422, E-mail: cylee@gntech.ac.kr 
increasing weight gain and feed conversion efficiency of the pigs. However, relative effects of extruded and extrudedpelleted ingredients vs. unprocessed counterparts are obscure primarily because extrusion processing is not commonly used for commercial diets other than those for the pet and fish because of its high processing cost (Hancock and Behnke, 2001). As an initial step to find the efficiency of the thermally processed corn in vivo, the present study was performed to investigate the effects of partial substitution of commercially available extruded and extruded-pelleted corn products for unprocessed corn of the starter diet on growth performance and incidence of diarrhea in weanling pigs.

\section{MATERIALS AND METHODS}

\section{Experimental diets}

A milk product-corn-soy-based starter diet used as the control contained 25\% unprocessed ground corn (Table 1). The other three diets contained $12.5 \%$ extruded corn Suprex ${ }^{\circledR}$ (Asia Feedflavor Inc., Ansan, Korea), Optigrain ${ }^{\circledR}$ (Kampffmeyer Food Innovation GmbH, Hamburg, Germany), an extruded mixture of corn, rye and durum, or extruded-pelleted (EP) corn substituted for an equal percentage of unprocessed corn. All the experimental diets were formulated to have identical densities or percentages of $\mathrm{DE}$, crude protein, lysine, and other nutrients which exceeded the recommendations for early post-weaning pigs between 5 and $10 \mathrm{~kg}$ (NRC, 1998), with an exception for crude protein. In addition, $100 \mathrm{ppm}$ sulfathiazone, $50 \mathrm{ppm}$ penicillin and $100 \mathrm{ppm}$ chlortetracycline were added to all diets as a means of preventive medication. The experimental diets were manufactured at once and stored at a $4^{\circ} \mathrm{C}$ cold room, from which aliquots were transported to the nursery building a few times a week and stored there until used.

\section{Animals}

Two serial feeding trials were performed during summer spanning from late June through mid-August in a completely randomized block design. In each trial, a total of 72 (Yorkshire $\times$ Landrace $) \times$ Duroc female and castrated male piglets were randomly allotted to four dietary treatments described above at weaning at $\mathrm{d} 21$ of age. Each treatment was assigned six $0.83-\mathrm{m}^{2}$ pens, with three animals allocated per pen. The animals were adapted to the assigned diet for
Table 1. Composition of the experimental diets (as-fed basis)

\begin{tabular}{lr}
\hline Item & Content \\
\hline \hline Ingredient, \% & \\
Unprocessed corn & 12.5 \\
Processed corn & \\
Whey powder & 12.5 \\
Lactose & 15.0 \\
Sucrose & 10.0 \\
Wheat flour & 2.0 \\
Soybean meal, dehulled & 7.4 \\
Pepsoygen ${ }^{\circledR 2)}$ & 18.0 \\
Fish meal & 10.0 \\
Soy oil & 5.0 \\
Limestone & 5.5 \\
Dicalcium phosphate & 0.5 \\
Salt & 0.9 \\
L-ysine & 0.2 \\
Vitamin premix & 0.1 \\
Mineral premix & 0.1 \\
Probiotics & 0.1 \\
Antibiotics & \\
Total & 0.1 \\
\hline Cal & 0.1 \\
\hline
\end{tabular}

Calculated chemical composition

$\mathrm{DE}, \mathrm{Mcal} / \mathrm{kg} \quad 3.71$

Crude protein, \% 22.1

Lysine, \% 1.39

Crude fat, \% $\quad 7.59$

$\mathrm{Ca}, \% \quad 0.80$

$\mathrm{P}, \% \quad 0.70$

${ }^{1)}$ Extruded corn Suprex ${ }^{\circledR}$ (Asia Feedflavor Inc., Ansan, Korea), Optigrain $^{\circledR}$ (Kampffmeyer Food Innovation $\mathrm{GmbH}$, Hamburg, Germany), an extruded mixture of wheat, rye and durum, extrudedpelleted (EP) corn, or unprocessed corn.

${ }^{2)}$ A fermented soy product (Genebiotech, Seoul, Korea).

${ }^{3)}$ Contained $100 \mathrm{ppm}$ sulfathiazone, $50 \mathrm{ppm}$ penicillin, and $100 \mathrm{ppm}$ chlortetracycline.

five days, after which the ad libitum intake of the diet was recorded for three weeks from Jun. 24 through July 15 . Water was freely accessible through the water cup equipped in each pen. The second feeding trial was performed from July 22 through Aug. 12 following a 5-day adaptation period to the assigned diet exactly as in the first trial on those pens which had been used in the first trial and subsequently washed and dried. The fecal consistency was scored 
subjectively twice a week according to the 3-point scale (Marquardt et al., 1999) as described by Zhao et al. (2012).

\section{Statistical analysis}

Data were analyzed as a completely randomized block design, with the feeding trial regarded as a 'fixed' block (Kaps and Lamberson, 2009), using the GLM procedure of SAS (1996). Pen was the experimental unit in all analyses. Means were compared by using the PDIFF option.

\section{RESULTS}

All the weanling pigs grew normally during the whole experimental period, the mortalities being $1.4 \%$ and $2.8 \%$ during the first and second feeding trials, respectively. Initial weight of the weanling pigs was greater in the first feeding trial than in the second trial (Table 2). Moreover, this variable was greatest in the Suprex ${ }^{\circledR}$ corn group and least in the group provided with the control diet containing no processed corn. Final weight was also greater in the first trial than in the second trial. However, when initial weight was included in the model as a covariate, final weight, which was highly correlated with the initial weight $(\mathrm{r}=0.60$; $\mathrm{P}<0.01)$, did not differ between the two trials (13.54 vs. $13.62 \mathrm{~kg}$ for the $1^{\text {st }}$ vs. $2^{\text {nd }}$ trial; $\mathrm{P}=0.86$ ). Unlike the initial weight, however, final weight was not different among the four dietary groups because of large variation among treatments.

The ADG was not different either between the two trials or among the dietary groups. The ADFI was greater in the second vs. first trial whereas the gain : feed ratio was greater in the latter. In addition, no differences among the four dietary groups were detected in these two variables.

The animals exhibited the normal feces in almost all the pens in both feeding trials (Table 3). The fecal consistency score therefore was not different either between the two feeding trials or among the four dietary groups.

Table 2. Effects of partial substitution of the processed corn product for unprocessed corn in the starter diet on growth performance of weanling pigs

\begin{tabular}{|c|c|c|c|c|c|c|c|c|}
\hline \multirow[b]{2}{*}{ Item } & \multicolumn{3}{|c|}{ Trial $^{1)}$} & \multicolumn{5}{|c|}{ Dietary treatment ${ }^{2}$} \\
\hline & $1^{\mathrm{st}}$ & $2^{\text {nd }}$ & $\mathrm{SEM}^{3)}$ & $\begin{array}{c}\text { Unprocessed } \\
\text { corn }\end{array}$ & $\begin{array}{c}\text { Suprex } \\
\text { corn }\end{array}$ & Optigrain $^{\circledR}$ & EP corn & $\mathrm{SEM}^{3)}$ \\
\hline Initial wt, $\mathrm{kg}$ & $6.18^{\mathrm{a}}$ & $5.63^{b}$ & 0.09 & $5.66^{\mathrm{c}}$ & $6.15^{\mathrm{a}}$ & $6.13^{\mathrm{ab}}$ & $5.68^{\mathrm{bc}}$ & 0.12 \\
\hline Final wt, $\mathrm{kg}$ & $14.03^{\mathrm{a}}$ & $13.13^{\mathrm{b}}$ & 0.30 & 13.11 & 13.77 & 13.99 & 13.43 & 0.42 \\
\hline $\mathrm{ADG}, \mathrm{kg}$ & 0.37 & 0.36 & 0.01 & 0.36 & 0.36 & 0.37 & 0.37 & 0.02 \\
\hline ADFI, $\mathrm{kg}$ & $0.97^{\mathrm{b}}$ & $1.05^{\mathrm{a}}$ & 0.02 & 0.99 & 1.05 & 1.02 & 0.98 & 0.02 \\
\hline Gain:feed & $0.38^{\mathrm{a}}$ & $0.35^{\mathrm{b}}$ & 0.01 & 0.36 & 0.35 & 0.37 & 0.38 & 0.02 \\
\hline Mortality, \% & 1.4 & 2.8 & - & 0 & 5.6 & 2.8 & 0 & - \\
\hline
\end{tabular}

${ }^{1), 2)}$ Data are means of 24 and 12 pens, respectively. There was no interaction between the two classes of fixed error in any of the variables.

2) See the table 1 legend for details of the processed corn products.

3) Standard error of means.

${ }_{\text {a,b,c }}$ Means with no common superscript in a row for a variable under a given column heading $\operatorname{differ}(\mathrm{P}<0.05)$.

Table 3. Effects of partial substitution of the processed corn product for unprocessed corn in the starter diet on the fecal consistency score of nursery pigs ${ }^{1)}$

\begin{tabular}{|c|c|c|c|c|c|c|c|}
\hline \multicolumn{3}{|c|}{ Trial $^{2)}$} & \multicolumn{5}{|c|}{ Processed corn ${ }^{3)}$} \\
\hline $1^{\mathrm{st}}$ & $2^{\text {nd }}$ & SEM $^{4)}$ & Unprocessed corn & Suprex ${ }^{\circledR}$ corn & Optigrain $^{B}$ & EP corn & SEM $^{4)}$ \\
\hline 1.00 & 1.03 & 0.02 & 1.00 & 1.06 & 1.00 & 1.00 & 0.02 \\
\hline
\end{tabular}

1) Fecal consistency score: $1=$ well formed; 2 = sloppy; 3 = diarrhea.

2),3) Data are means of 24 and 12 pens, respectively. There was no interaction between the two classes of fixed error.

3) See the table 1 legend for details of the processed corn products.

4) Standard error of means. 
Park et al. ; Processed Corn in Pig Starter Diet

\section{DISCUSSION}

The reduced initial weight of the weanling pigs in the second vs. first trial is most likely to have resulted from a reduced sow's milk production due to the high temperature during early to mid-July (Azain et al., 1996; Spencer et al., 2003) preceding the second trial compared with that during early to mid-June preceding the first trial. On the other hand, the non-uniform initial weights of the four dietary groups were due to random effects whereas the greater final weight in the first vs. second trial was attributable to the greater initial weight in the former as indicated from covariance and correlation analyses. However, there is no convincing explanation as to why ADFI was greater in the second vs. first trial whereas the gain: feed was greater in the latter. In this connection, only limited and inconsistent results are available as to the effects of pig weaning weight on feed intake and its efficiency during the nursery phase (Mahan and Lepine, 1991; Mahan et al., 1998).

Partial substitution of the extruded or extruded-pelleted corn product for unprocessed corn of the basal diet did not influence weight gain or feed conversion efficiency in the present study. This is not surprising, not only because growth performance is not usually affected by extruding or expanding the major grain ingredient or complete diet in young pigs (Noland et al., 1976; Ginste and De Schrijver, 1998; Hongtrakul et al., 1998; Lundblad et al., 2011), but because the percentage of the processed corn in the experimental diet (12.5\%) was lower than those used in these studies. It thus seems apparent that use of the thermally processed corn at a low percentage in a milk product-cornsoy-based pig starter diet has no effect on growth performance although energy and $\mathrm{N}$ digestibilities are increased following the thermal processing (Sauer et al., 1990; Lv et al., 2006; Lundblad et al., 2012). It will be therefore necessary to increase the percentage of the processed corn to a level higher than that of the present diets to determine the effect of the processed corn on growth performance in young pigs.

The extremely low incidence of diarrhea in the present study may be partly due to supplemental antibiotics which were added to all experimental diets as a means of preventive medication to minimize any confounding effect of the subclinical health problem secondary to the weaning stress (Weary et al., 2008). The diarrhea-reducing effect of extruded corn in the pig starter diet reported by Lv et al.
(2006) therefore could not be confirmed in the present study. Obviously, more studies are necessary to work out the effects of the thermally or hydrothermally processed corn on diarrhea incidence as well as growth performance in young pigs.

\section{ACKNOWLEDGMENTS}

This work was supported by grants from Gyeongnam National University of Science and Technology (GNTech) and Regional Animal Industry Center at GNTech. We authors thank Mr. Seung Ho Ha for manufacturing the experimental diets and Dr. Man-Jong Park for the assistance with the feeding trial.

\section{REFERENCES}

Azain, M. J., Tomkins, T., Sowinski, J. S., Arentson, R. A. and Jewell, D. E. 1996. Effect of supplemental pig milk replacer on litter performance: seasonal variation in response. J. Anim. Sci. 74:2195-2202.

Ginste, J. V. and De Schrijver, R. 1998. Expansion and pelleting of starter, grower and finisher diets for pigs: effects on nitrogen retension, ileal and total tract digestibility of protein, phosphorus and calcium and in vitro protein quality. Anim. Feed Sci. Technol. 72:303-314.

Han, I. K., Paik, I. K., Choi, Y. J., Kim, B. K. and Seo, S. W. 2011. Feedstuff Handbook. 4th ed. Han's Animal Science Life Foundation and Korean Society of Animal Nutrition \& Feedstuffs.

Hancock, J. D. and Behnke, K. C. 2001. Use of ingredient and diet processing technologies (grinding, mixing, pelleting, and extruding) to produce quality feeds for pigs. In: Swine Nutrition. $2^{\text {nd }}$ ed. (eds. A. J. Lewis and L. L. Southern), CRC Press, Boca Raton, FL, USA, pp. 469-497.

Herkelman, K. L., Rodhouse, S. L., Veum, T. L. and Ellersieck, M. R. 1990. Effect of extrusion on the ileal and fecal digestibilities of lysine in yellow corn in diets for young pigs. J. Anim. Sci. 68:2414-2424.

Hongtrakul, K., Goodband, R. D., Behnke, K. C., Nelssen, J. L., Tokach, M. D., Bergstrom, J. R., Nessmith, W. B., Jr. and Kim, I. H. 1998. The effects of extrusion processing of carbohydrate sources on weanling pig performance. J. Anim. Sci. 76:3034-3042.

Kaps, M. and Lamberson, W. 2009. Biostatics for Animal Science. $2^{\text {nd }}$ ed. CAB International, Cambridge, USA. 
Li, Y., Fang, Z., Dai, J., Partridge, G., Ru, Y. and Peng, J. 2010. Corn extrusion and enzyme addition improves digestibility of corn/soy based diets by pigs: in vitro and in vivo studies. Anim. Feed Sci. Technol. 158:146-154.

Lundblad, K. K., Hancock, J. D., Behnke, K. C., McKinney, L. J., Alavi, S., Prestlokken, E. and Sorensen, M. 2012. Ileal digestibility of crude protein, amino acids, dry matter and phosphorous in pigs fed diets steam conditioned at low and high temperature, expander conditioned or extruder processed. Anim. Feed Sci. Technol. 172:237-241.

Lundblad, K. K., Issa, S., Hancock, J. D., Behnke, K. C., McKinney, L. J., Alavi, S., Prestlokken, E., Fledderus, J. and Sorensen, M. 2011. Effects of steam conditioning at low and high temperature, expander conditioning and extruder processing prior to pelleting on growth performance and nutrient digestibility in nursery pigs and broiler chickens. Anim. Feed Sci. Technol. 169:208-217.

Lv, S., Li, D., Xing, J., Yongxi, M., Huang, D. and Li, J. 2006. Effects of extrusion of corn on growth performance, nutrient digestibility and short-chain fatty acid profiles in the hindgut of weaned piglets. Arch. Anim. Nutr. 60:170-179.

Mahan, D. C., Cromwell, G. L., Ewan, R. C., Hamilton, C. R. and Yen, J. T. 1998. Evaluation of the feeding duration of a phase 1 nursery diet to three-week-old pigs of two weaning weights. J. Anim. Sci. 76:578-583.

Mahan, D. C. and Lepine, A. J. 1991. Effect of pig weaning weight and associated nursery feeding programs on subsequent performance to 105 kilograms body weight. J. Anim. Sci. 69: 1370-1378.

Marquardt, R. R., Jin, L. Z., Kim, J. W., Fang, L., Frohlich, A. A. and Baidoo, S. K. 1999. Passive protective effect of egg-yolk antibodies against enterotoxigenic Escherichia coli K88+ infection in neonatal and early-weaned piglets. FEMS Immunol. Med. Microbiol. 23:283-288.

Noland, P. R., Campbell, D. R., Gage, R. K., Jr., Sharp, R. N. and Johnson, Z. B. 1976. Evaluation of processed soybeans and grains in diets for young pigs. J. Anim. Sci. 43:763-769.

NRC. 1998. Nutrient Requirements of Swine. $10^{\text {th }}$ ed. National Academy Press, Washington, D.C.

Peisker, M. 1994. Influence of expansion on feed components. Feed Mix 2:26-31.

SAS. 1996. SAS User's Guide: Statistics. SAS Inst., Inc., Cary, NC, USA.

Sauer, W. C., Mosenthin, R. and Pierce, A. B. 1990. The utilization of pelleted, extruded, and extruded and pelleted diets by early weaned pigs. Anim. Feed Sci. Technol. 31: 269-275.

Schields, R. G., Jr., Ekstrom, K. E. and Mahan, D. C. 1980. Effect of weaning age and feeding method on digestive enzyme development in swine from birth to ten weeks. J. Anim. Sci. 50:257-265.

Spencer, J. D., Boyd, R. D., Cabrera, R. and Allee, G. L. 2003. Early weaning to reduce tissue mobilization in lactating sows and milk supplementation to enhance pig weaning weight during extreme heat stress. J. Anim. Sci. 81:2041-2051.

Weary, D. M., Jasper, J. J. and Hotzel, M. J. 2008. Understanding weaning stress. Appl. Anim. Behav. Sci. 110:24-41.

Wondra, K. J., Hancock, J. D., Behnke, K. C., Hines, R. H. and Stark, C. R. 1995a. Effect of particle size and pelleting on growth performance, nutrient digestibility, and stomach morphology in finishing pigs. J. Anim. Sci. 73:757-763.

Wondra, K. J., Hancock, J. D., Behnke, K. C. and Stark, C. R. 1995b. Effects of mill type and particle size uniformity on growth performance, nutrient digestibility, and stomach morphology in finishing pigs. J. Anim. Sci. 73:2564-2573.

Zhao, P. Y., Jung, J. H. and Kim, I. H. 2012. Effect of mannan oligosaccharides and fructan on growth performance, nutrient digestibility, blood profile, and diarrhea score in weanling pigs. J. Anim. Sci. 90:833-839.

(Received Mar. 12, 2013; Revised Apr. 25, 2013; Accepted Apr. 25, 2013) 